\title{
Advice for New Authors on the Submission of Articles I Conseils pour les nouveaux auteurs sur la soumission d'articles
}

\author{
Peter R. Elson \\ Mount Royal University \\ Francois Brouard \\ Carleton University
}

\begin{abstract}
New authors often see the publication process as a mystery that only gets revealed in bits and pieces over time. This article aims to present some tips and ideas to new authors to facilitate the submission of an article to Canadian Journal of Nonprofit and Social Economy Research / Revue canadienne de recherche sur les OSBL et l'économie sociale (ANSERJ). It describes the review process and highlights some key milestones. As the English Language and French Language editors for ANSERJ, we would like to encourage new contributors, and thus we will highlight specific items as they apply to ANSERJ. These guidelines complement the author guidelines already posted on the ANSERJ website. Our advice may apply to authors interested in other journals with a peer review process.
\end{abstract}

\section{RÉSUMÉ}

Les nouveaux auteurs considèrent souvent le processus de publication comme un mystère qui se découvre au fil du temps. Cet article vise à présenter certains conseils et réflexions pour faciliter la soumission d'un article à la Revue canadienne de recherche sur les OSBL et l'économie sociale / Canadian Journal of Nonprofit and Social Economy Research (ANSERJ). II décrit le processus de publication et ses étapes principales. À titre de rédacteurs en chef d'ANSERJ, nous aimerions encourager les nouveaux chercheurs, contribuer au débat par quelques conseils et réflexions et souligner certains éléments spécifiques à notre revue. Les présentes réflexions complètent les directives déjà présentes sur le site web de la revue. Ils peuvent s'appliquer à des auteurs intéressés par d'autres revues avec comité de lecture.

Keywords / Mots clés : Publishing; Journal; Advice / Publication; Revue; Conseils 


\section{Elson and / et Brouard (2012)}

\section{INTRODUCTION}

Publishing an article in a refereed journal is an important contribution to the dissemination of knowledge. A publication by a new or experienced university researcher is important on several levels. It may be an integral part of acquiring tenure, obtaining a promotion or an award, or progressing to a new salary level; it may also be part of scholarship and teaching activities (Swanson, 2004). Publishing in a refereed journal can be examined from several perspectives, since the ultimate publication of an article requires the collaboration of multiple actors; namely, author, editor, reviewer, and publisher (Lange, 2005).

The views of authors and reviewers have been the subject of several reflective conference presentations and journal publications (Adler and Liyanarachchi, 2011; Harrison, 2002; Lange, 2005; Mautz, 1987; Swanson, 2004). As editors of the Canadian Journal of Nonprofit and Social Economy Research / Revue canadienne de recherche sur les OSBL et l'économie sociale (ANSERJ), we would like to contribute to this topic with some tips and ideas, and highlight specific items relevant to ANSERJ. While these comments are primarily aimed at new authors who submit an article to ANSERJ, they may apply to anyone interested in making a submission to a journal with a peer review process. This advice complements the author guidelines already posted on the ANSERJ website (www.anserj.ca).

These tips and ideas should be of particular interest to new researchers. The intention of this article is to demystify the evaluation and publishing process for submitted articles, at ANSERJ and in general. However, there is no magic substitute for clear and relevant research, a solid initial text, selecting an appropriate journal, and revising your text after submission.

\section{BUILDING BLOCKS}

The publication of an article is a complex process, including standards that may vary according to theme, discipline, and time of submission (Swanson, 2004). The editorial review process is based on the evaluation of articles by reviewers who are not only competent evaluators, but also independent, objective, and anonymous to authors (Mautz, 1987). For editors, it is essential to find relevant articles, rigorously prepared, that contribute to building knowledge.

There are several decision levels in the process that leads to the publication of an article. Table 1 shows the main steps in the review process. These include the preparation of an article, its submission, evaluation, or revision, the decision to accept or reject an article, and the processes of editing, publication and dissemination. It is understood that some of these steps may be repeated, as in the review stage. These various steps are the responsibility of the author or authors, who will navigate their submission through these stages, with the editor acting as a go-between between authors and reviewers.

It may be helpful to situate this process in an analytical framework. A "q-r" theory proposed by Ellison (2002a, 2002b) distinguishes between two aspects of quality: 1) quality "q" is the level of importance of the subject and the relevance of its research question, and 2) quality " $r$ " is the rigour demonstrated in research, the methodology used and the consistency of all to tell the story (Ellison, 2002a, 2002b; Swanson, 2004). 
Elson and / et Brouard (2012)

Table 1: Key steps in the process of journal publication

\begin{tabular}{|c|c|c|c|}
\hline & \multicolumn{3}{|c|}{ Responsibilities } \\
\hline & Author (s) & Editor & Reviewers \\
\hline Research work & $x$ & & \\
\hline Selection of the journal & $\mathrm{x}$ & & \\
\hline Read standards of the journal & $\mathrm{x}$ & & \\
\hline Article writing & $\mathrm{x}$ & & \\
\hline Dissemination at conferences and circulation to peers & $\mathrm{x}$ & & \\
\hline Submission to a journal & $x$ & & \\
\hline Receiving a submission & & $\mathrm{x}$ & \\
\hline $\begin{array}{l}\text { Initial decision } \\
\text { - Initial rejection } \\
\text { - Request for initial revisions } \\
\text { - Sending to reviewers }\end{array}$ & & $\mathrm{x}$ & \\
\hline Receipt of the decision of initial rejection or required revisions & $\mathrm{x}$ & & \\
\hline Second submission to the journal, if any & $\mathrm{x}$ & & \\
\hline Selection of reviewers & & $\mathrm{x}$ & \\
\hline Article rating and review & & & $\mathrm{x}$ \\
\hline Reviews writing & & & $\mathrm{x}$ \\
\hline Submission of reviews & & & $\mathrm{x}$ \\
\hline Receipt of reviews by editor & & $\mathrm{x}$ & \\
\hline Consolidation and analysis of the reviews & & $\mathrm{x}$ & \\
\hline $\begin{array}{l}\text { Decision } \\
\text { - Acceptance without modification } \\
\text { - Acceptance with minor modifications } \\
\text { - Acceptance with major revisions } \\
\text { - Rejection }\end{array}$ & & $x$ & \\
\hline Receipt of the decision by author & $\mathrm{x}$ & & \\
\hline Preparation of requested revisions & $\mathrm{x}$ & & \\
\hline $\begin{array}{l}\text { Resubmission of the revised article with the revisions requested } \\
\text { and justifications }\end{array}$ & $x$ & & \\
\hline $\begin{array}{l}\text { Receipt of the revised article with the revisions requested and } \\
\text { justifications }\end{array}$ & & $\mathrm{x}$ & \\
\hline Examination of the acceptability of revisions & & $\mathrm{x}$ & \\
\hline Final decision & & $\mathrm{x}$ & \\
\hline Receipt of the final decision, by author & $\mathrm{x}$ & & \\
\hline Supervision / monitoring of journal editing & & $\mathrm{x}$ & \\
\hline Approval of edited article for publication & & $\mathrm{x}$ & \\
\hline Publication of the article & & $\mathrm{x}$ & \\
\hline Dissemination of the article & $\mathrm{x}$ & $x$ & \\
\hline
\end{tabular}

\section{PREPARATION BEFORE SUBMISSION}

We will assume here that you have conducted some research and wish to see some or all of it published in a journal. The current state of this research may be in the form of a thesis or research report. While we make no judgment about the nature of your research, a journal article is, by its very nature, relatively brief (maximum 8,000 words for ANSERJ) and self-contained, and it contributes to knowledge, theory, methodology, and possibly practice. 


\section{Elson and / et Brouard (2012)}

\section{Know your journal}

Whether it is in ANSERJ or another journal, take time to read published articles in your field. You may have read them before for their content, but in this case you are reading them for style, clarity, coherence, and concision (Williams, 1995). You will find that there is often a common format, regardless of the topic or research methodology. For example, many articles begin with a contextual introduction, identifying why the research is important, followed by a critical synopsis of the existing literature; an overview of the methodology; research findings; discussion; and a conclusion with appropriate implications.

While this may be a common format, it is by no means the only one. Theoretical, philosophical, or historical articles may differ considerably, and ANSERJ does not subscribe to any particular methodological or disciplinary preference. Your presentation needs to be consistent with your methodology and research question. The research question is of paramount importance in guiding all elements of research design (Maxwell, 1998). Choose a journal that matches the quality of your work and the target audience. Read the guidelines for authors carefully, including the requirements for referencing. Disregard for author guidelines and ignorance of the journal's content or audience will give a poor first impression. Keep an eye out for special issues and judge your timing accordingly. Never hesitate to contact an editor directly to clarify any process or timing issues.

Take advantage of library staff, colleagues or supervisors with special expertise in research. These contacts can help you find relevant journals and their submission and publication guidelines. It is possible that there are more journals than you think. While we hope that ANSERJ will be one of your choices, your decision should be weighted toward the best match between the objectives of the journal and your research goals.

ANSERJ is an open-access, online, dual-language journal; therefore there are no submission or subscription fees. By registering with ANSERJ, libraries and other subscribers receive notices of new issues. The more libraries and databases subscribe to or list ANSERJ, the better the chance that your article will be read and quoted.

\section{Getting your submission ready}

Your article is not a cut and paste from a thesis or research report. It is a distinct entity and may often require additional research beyond what you have already completed, particularly if your original research is not grounded in a clear research question.

"The most important thing, bar none, is to produce good research," says Jane Freeman from the University of Toronto, "important, discipline-advancing, well-supported research. No gimmicks, no tips on publishing will get you published if you have nothing worthwhile to say." (Lemon, 2006, p. S11)

Give yourself an incentive to get published. Set yourself a goal to publish an article, even if this means simply a good quality and non-peer-reviewed article. Think of each paper you write as a potential article. Too many people wait until they have finished their graduate studies to publish an article. Remember that most reviews are blind, so your work should speak for itself. Editors are often willing to provide preliminary feedback on whether an idea for an article is suitable for their journal. The editors at ANSERJ are certainly willing to do this. (Remember, though, that this doesn't mean it will be published when you do submit it!)

One good article a year is better than three that have all been rejected or require so many changes that you might have to start from scratch. There will be common expectations in your field regarding frequency of publication. Know what they are and start to prepare yourself as early as possible. 


\section{Elson and / et Brouard (2012)}

It is easy to be sentimental about your work and its importance, but blind reviewers are looking for quality, concision and coherence in your article. If you have not taken a workshop or course on self-editing, consider doing so. Schools of graduate studies or related departments often offer such courses.

Pay attention to length. There may be some flexibility, but submitting a 15,000-word article when the stated limit is 8,000 (as with ANSERJ) can leave editors with a poor initial impression and can create extra work, even before the submission is reviewed. Too often information is included that would be important in a thesis but is not germane to the focus of an article. A literature review, for example, should be specific to the research question addressed by the article and should not be a broad review of all literature.

Language is also important. ANSERJ has a very broad audience and jargon and acronyms that are not generally understood should be avoided. In the same vein, key terms should be used consistently across an article. Writers often change terms in an attempt to make an article more interesting, when in fact it only creates confusion. ANSERJ publishes in two languages - English and French - and only in the language that is submitted.

\section{Initial circulation of an article for comment}

Before exposing your article to blind reviewers, consider identifying colleagues who are willing to read initial drafts and provide feedback. This can be done at conferences or by asking colleagues or a supervisor. Colleagues need not necessarily be experts in the subject matter. Choose individuals with whom you have a relationship of trust, who have a variety of perspectives, and who are familiar with your work and with journal publishing. The best advice will be from those who have no vested interest in telling you that your draft is great when in fact it needs considerable work.

\section{SUBMISSION AND REVIEWS}

Submitting an article and not following up is like hitting a baseball and forgetting to run the bases. You should receive an immediate acknowledgement of your submission. If not, follow up right away. This is particularly important with online submissions, as there may be a glitch in the system. If you do not hear back from an editor within a couple of weeks, assume that your submission has been sent for external review. This is a process that can take a minimum of four to six weeks and often much longer, so you need to be patient. Some reviewers do not follow through on commitments, and this can cause unexpected delays in the process. It is not a reflection of your submission.

\section{Editor's initial decision}

It is possible that the editor will initially request changes before the article is sent out for review. If you have major gaps in your article, such as an insufficient literature review, methodology section or conclusion, these will likely need to be added before it is circulated. It is also possible that the editor will decide not to proceed with a review if the article lacks relevance or research rigour.

\section{The blind review and decision}

A blind review occurs when the reviewers do not know who you are and vice versa. Every step is taken to protect this process. All reviewers for ANSERJ are asked if there is a possible conflict of interest, even from reading an abstract of the article. Where there is such a conflict, alternative reviewers are identified. Most reviewers are very busy, so with 


\section{Elson and / et Brouard (2012)}

ANSERJ, every effort is taken to match reviewers to the content of the article. This means that the review is likely to be of high quality and the reviewer is very familiar with the field of research.

ANSERJ strives to identify at least two or three reviewers for each article. These reviewers can be from anywhere in the world. Often reviewers for ANSERJ take time to write several pages of comments and suggestions. This is extremely valuable for both the quality of the final article and your development as a writer. It is critical to read all reviewers' comments thoroughly for two reasons: First, reviewers have different perspectives and you may need to reconcile variations in their comments; and second, it is expected, when you revise an article for ANSERJ, that you will itemize your changes in a separate document that will be forwarded to the reviewers. ANSERJ editors will often highlight the reviewers' suggestions that should definitely be addressed.

Regardless of the nature of the feedback you receive, only "no"' means no and anything less means that you can choose to make revisions. Remember that multiple revisions and re-submissions for a peer-reviewed article are the norm, not the exception. When you make your revisions, it is important to understand that these are to be taken seriously. If you can clearly justify why a recommended change should not be made, you have the opportunity to do so when you submit an itemized list of changes you have made with your re-submission. Making changes will often lengthen the article, yet the need for clarity, coherence, and concision still applies. Upon receipt of reviewers' comments, editors may reject an article due to the following: problems with the research question; a serious research design deficiency; a lack of consistency; or insignificance of the article to the field (Mautz, 1987). When the problems are too numerous, the editor will often reject the article instead of striving to improve it. Editors are fallible, and history tells us that misjudgments are made, as was the case for several now-classic, but initially rejected articles by Nobel Prize winners (Gans and Shepherd, 1994). We do our best to give each and every article a fair and thorough assessment, providing as much guidance as is appropriate along the way.

In ANSERJ, the editor is responsible for content editing before the article is copyedited by the journal publisher. At this time you will be asked for biographic information and acknowledgements that you may wish to make.

\section{CELEBRATING YOUR SUCCESS}

The successful publication of your article is both a personal and professional achievement. You can support the journal and your career by making as many people as possible aware of it. Post your abstract and article title on your social media outlets and make sure that you update your $\mathrm{CV}$ to include your new publication. For its part, ANSERJ distributes all of its published articles through Open Journal Systems (OJS), ProQuest, and EBSCO. An application has also been submitted to have ANSERJ posted on the U.K. open journal database, the Directory of Open Access Journals (DOAJ).

\section{CONCLUSION}

The mystery associated with getting published is sometimes rooted in inadequate knowledge of the process itself. It takes patience and perseverance to see any research in print, and we hope this guide will serve as an aid to those seeking publication. Contributing to knowledge is what research is all about, and knowledge dissemination is the raison d'être of publishing. 


\section{Conseils pour les nouveaux auteurs sur la soumission d'articles / Advice for New Authors on the Submission of Articles}

\section{INTRODUCTION}

Publier un article dans une revue avec comité de lecture est un acte important pour la diffusion de la connaissance. Une publication réussie par un chercheur universitaire débutant ou expérimenté est importante à plusieurs niveaux. II peut s'agir de l'embauche dans un poste de professeur, de l'acquisition de la permanence, de l'obtention d'une promotion ou d'un prix, du niveau salarial obtenu ou de la charge d'enseignement, pour ne nommer que quelques exemples (Swanson, 2004). On peut examiner la publication d'articles dans une revue avec comité de lecture à partir de plusieurs points de vue, puisque la publication d'un article exige un travail collaboration parmi de divers acteurs : des auteurs, des évaluateurs et des rédacteurs en chef (Lange, 2005).

Le point de vue des auteurs et des évaluateurs a fait l'objet de plusieurs réflexions que ce soit lors de conférences ou dans des publications (Adler et Liyanarachchi, 2011; Harrison, 2002; Lange, 2005; Mautz, 1987; Swanson, 2004). À titre de la rédacteurs en chef Revue canadienne de recherche sur les OSBL et l'économie sociale / Canadian Journal of Nonprofit and Social Economy Research (ANSERJ), nous aimerions contribuer au débat par quelques conseils et réflexions et souligner certains éléments spécifiques à notre revue. Même si les commentaires exprimés visent principalement à la soumission d'un article à ANSERJ, ils peuvent s'appliquer à des auteurs intéressés aux autres revues avec comité de lecture. Les présentes réflexions complètent les directives déjà présentes sur le site web de la revue (www.anserj.ca).

Ces conseils et réflexions devraient intéresser particulièrement les nouveaux chercheurs. L'intention de cet article est de démystifier le processus de publication et d'évaluation des articles soumis. Toutefois, comme vous le constaterez à la lecture de nos commentaires, il n'y a pas de recettes magiques remplaçant une recherche claire et pertinente et le besoin d'écrire un texte solide au départ, de le soumettre au bon endroit et d'être prêt à réviser le texte suite aux commentaires reçus.

\section{ÉTABLIR DE SOLIDES FONDATIONS}

La publication d'un article est un processus complexe, incluant des normes variant selon divers axes comme les thèmes étudiés, la discipline et le moment de la soumission (Swanson, 2004). Le processus suivi dans l'évaluation des articles s'appuie sur certains principes, tels que la compétence des évaluateurs, leur indépendance, l'objectivité dont ils font preuve, l'anonymat des auteurs et des évaluateurs (Mautz, 1987). Pour les rédacteurs en chef, il s'agit essentiellement de trouver des articles pertinents, préparés avec rigueur et apportant une contribution aux connaissances.

Le processus suivi vers la publication d'un article amène plusieurs niveaux de décision. Le tableau 1 présente les principales étapes du processus, soit le travail de préparation d'un article, la soumission, l'évaluation, la révision, la décision d'accepter ou de rejeter un article, l'édition, la publication et la diffusion. II est bien entendu que certaines de ces étapes puissent se répéter, comme l'étape de la révision. Ces diverses étapes sont sous la responsabilité de l'auteur ou des auteurs, qui doivent négocier entre eux les différentes étapes qui leur concernent, ainsi que le rédacteur en chef et les évaluateurs. Certaines de ces étapes sont reprises dans les commentaires subséquents.

La théorie « q-r » proposée par Ellison (2002a, 2002b) nous aide à situer ce processus dans un cadre d'analyse. Brièvement, la théorie « q-r » distingue entre deux aspects de la qualité d'un article :1) la qualité « $q$ » correspond au niveau d'importance du sujet et de la pertinence de sa question de recherche et 2) la qualité « $r$ » correspond à 
la rigueur démontrée dans la recherche, à la méthodologie utilisée et à la cohérence de l'ensemble pour raconter I'histoire (Ellison, 2002a, 2002b; Swanson, 2004).

Tableau 1 : Principales étapes du processus de publication dans une revue

\begin{tabular}{|c|c|c|c|}
\hline & \multicolumn{3}{|c|}{ Responsabilités } \\
\hline & Auteur(s) & Rédacteur en chef & Évaluateurs \\
\hline Travail de recherche & $\mathrm{x}$ & & \\
\hline Sélection de la revue & $\mathrm{x}$ & & \\
\hline Lecture des normes de la revue & $\mathrm{x}$ & & \\
\hline Rédaction d'un article & $\mathrm{x}$ & & \\
\hline Diffusion lors de conférences et distribution & $\mathrm{x}$ & & \\
\hline Soumission à une revue & $\mathrm{x}$ & & \\
\hline Réception d'un article & & $\mathrm{x}$ & \\
\hline $\begin{array}{l}\text { Décision initiale } \\
\text { - rejet initial } \\
\text { - demande de révisions initiales } \\
\text { - envoi aux évaluateurs }\end{array}$ & & $\mathrm{x}$ & \\
\hline $\begin{array}{l}\text { Réception de la décision } \\
\text { de rejet initial ou de révisions initiales }\end{array}$ & $\mathrm{x}$ & & \\
\hline Seconde soumission à la revue, s'il y a lieu & $\mathrm{x}$ & & \\
\hline Sélection des évaluateurs & & $\mathrm{x}$ & \\
\hline Évaluation de l'article & & & $x$ \\
\hline Rédaction des évaluations & & & $x$ \\
\hline Envoi de l'évaluation & & & $x$ \\
\hline Réception des évaluations par le rédacteur en chef & & $x$ & \\
\hline Consolidation et analyse des évaluations & & $\mathrm{x}$ & \\
\hline $\begin{array}{l}\text { Décision } \\
\text { - acceptation sans modification } \\
\text { - acceptation avec remaniement léger } \\
\text { - acceptation avec remaniement profond } \\
\text { - rejet }\end{array}$ & & $x$ & \\
\hline Réception de la décision par l'auteur & $\mathrm{x}$ & & \\
\hline Préparation des révisions demandées & $\mathrm{x}$ & & \\
\hline $\begin{array}{l}\text { Nouvelle soumission de l'article révisé avec les révisions } \\
\text { demandées et les justifications }\end{array}$ & $\mathrm{x}$ & & \\
\hline $\begin{array}{l}\text { Réception de l'article révisé avec les révisions demandées et } \\
\text { les justifications }\end{array}$ & & $\mathrm{x}$ & \\
\hline Examen de l'acceptabilité des révisions & & $x$ & \\
\hline Décision finale & & $\mathrm{x}$ & \\
\hline Réception de la décision finale par l'auteur & $\mathrm{x}$ & & \\
\hline Supervision de l'édition & & $\mathrm{x}$ & \\
\hline Approbation de l'article édité pour publication & & $\mathrm{x}$ & \\
\hline Publication de l'article & & $\mathrm{x}$ & \\
\hline Diffusion de l'article & $\mathrm{x}$ & $x$ & \\
\hline
\end{tabular}

\section{PRÉPARATION AVANT SOUMISSION}

Nous supposons que le travail de recherche a été conduit selon les règles de l'art et que l'auteur désire voir une partie ou la totalité de son travail publié dans une revue. L'état initial de sa recherche peut être une thèse ou un rapport de recherche. Un article de revue est relativement bref (maximum de 8000 mots pour ANSERJ), 


\section{Elson and / et Brouard (2012)}

autonome et apporte une contribution aux connaissances, à la théorie, à la méthodologie et possiblement à la pratique.

\section{Connaître la revue}

Que ce soit pour ANSERJ ou pour une autre revue, il est important de lire des articles publiés dans votre domaine. Il est possible que vous ayez déjà lu ces articles pour leur contenu, mais il s'agit maintenant de les lire pour leur style, leur clarté, leur cohérence et leur concision (Williams, 1995). Vous vous apercevrez qu'il y a souvent un format commun, peu importe le sujet ou la méthodologie de recherche. Par exemple, une majorité d'articles commencent par une introduction présentant le contexte et la question de recherche et justifiant l'importance de la recherche, suivi par une revue de la littérature courante, une description de la méthodologie, les résultats de recherche; une analyse des résultats et une conclusion indiquant les implications.

Même s'il s'agit d'une structure relativement fréquente, il ne s'agit en aucun cas de la seule valable. Des articles théoriques, philosophiques ou historiques peuvent différer considérablement et ANSERJ n'impose pas de méthodologies particulières ou préférables. La présentation de votre recherche doit être surtout cohérente avec votre méthodologie et votre question de recherche. La question de recherche est d'une importance capitale guidant l'ensemble des éléments du design de recherche (Maxwell, 1998). Choisissez une revue qui correspond à la qualité de votre travail et à votre clientèle. Prenez connaissance des règles de la revue, incluant les normes de présentation générales et celles pour la bibliographie. Un article qui fait preuve d'ignorance par rapport aux règles de soumission ou du public auquel le journal est destiné ne fera que mauvaise impression. II arrive aussi que les revues publient des numéros thématiques; il faut donc ouvrir l'œil à ce sujet. N'hésitez pas à contacter directement le rédacteur en chef pour clarifier le processus ou les délais.

Profitez du personnel à la bibliothèque, de vos collègues ou d'un directeur possédant une expertise particulière au niveau de la recherche. Ces personnes-ressources peuvent vous aider à trouver des revues pertinentes ainsi que leurs processus de publication. II est possible qu'il y ait plus de revues que vous ne le croyez. Même si nous espérons qu'ANSERJ représentera l'un de vos choix, votre décision devrait se baser principalement sur la meilleure correspondance entre les objectifs visés par la revue et les objectifs de votre recherche.

ANSERJ est une revue offerte en ligne, à libre-accès. II n'y a donc pas de frais d'abonnement. Plus il y a de bibliothèque qui s'abonne, meilleures sont les chances que votre article soit lu et cité. En plus, ANSERJ n'exige pas de frais pour la soumission d'un article, ce qui augmente le nombre d'articles soumis.

\section{Rédiger son article pour la soumission}

Votre article n'est pas une version copier/coller d'une thèse ou d'un rapport de recherche. II s'agit d'un document distinct qui peut souvent exiger de la recherche additionnelle par rapport au document original. Ceci arrive souvent si le travail initial n'est pas établi à partir d'une question de recherche claire ou s'il traite d'une question différente.

Jane Freeman de l'Université de Toronto est d'avis que: « La chose la plus importante est de réaliser un bonne recherche, pertinente, offrant une contribution et bien documentée. Aucune astuce ou conseil sur la publication ne vous permettra de publier, si l'auteur n'a rien à dire. » [traduction] (Lemon, 2006, p. S11)

Il est important de se fixer des objectifs en publication. Le talent d'un rédacteur se trouve dans sa capacité à écrire et à réviser son travail. La rédaction d'un article, même pour une revue sans comité de lecture, est un bon 


\section{Elson and / et Brouard (2012)}

exercice et peut servir d'objectif initial. II faut penser à chaque document comme un article potentiel. Trop d'étudiants attendent qu'ils aient fini leurs études avant de s'attaquer à la publication d'un article. II faut se rappeler que la plupart des évaluations se font à l'aveugle et que le travail présenté doit parler par lui-même. Les rédacteurs en chef sont souvent disponibles pour fournir des commentaires sur une idée ou sur la pertinence d'un sujet à leur revue. Les rédacteurs en chef d'ANSERJ sont certainement prêts à aider les auteurs. (II faut toutefois se rappeler que des conseils ne signifient pas que l'article sera accepté, une fois soumis!)

En ciblant la bonne revue et en soumettant un article de qualité, vous trouverez que les décisions positives seront nettement plus fréquentes. II vaut mieux avoir un seul bon article que trois articles rejetés ou qui nécessitent un nombre de changements tellement décourageant. Dans certains domaines ou universités, on attend chez les chercheurs une certaine fréquence de publication dans des revues d'une certaine qualité (Swanson, 2004). II est donc important de les connaître et de s'y préparer aussitôt que possible. Il est facile de devenir émotif à propos de son travail et de son importance. Toutefois, les évaluateurs ne cherchent que la qualité, la rigueur et la cohérence dans un article. Si vous n'avez jamais suivi un atelier sur la publication, considerez-le. Les universités et les programmes d'études avancées offrent de tels cours.

Faites attention à la longueur. Même s'il y a un peu de flexibilité au niveau de la longueur, un article de 15000 mots alors que la limite annoncée est de 8000 mots (comme chez ANSERJ) démontre que l'auteur n'a pas pris le temps de lire les règles de la revue; qu'il s'attend à ce que le rédacteur en chef ou les évaluateurs décident de ce qui est important; ou qu'il ne veut pas prendre le temps d'enlever certaines parties bien intéressantes mais non essentielles. Trop souvent, l'information incluse est importante pour une thèse mais pas pour un article. Par exemple, la revue de la littérature doit être spécifique à votre question de recherche discutée et non une revue trop générale.

Le langage est important. ANSERJ s'adresse à un public étendue et, par conséquence, on y évite l'utilisation de jargon et d'acronymes. De même, on exige que les termes soient utilisés d'une manière régulière tout au long de l'article. Les auteurs utilisent souvent des synonymes afin de rendre leur article plus intéressant, mais cela n'a pour effet que de semer de la confusion. ANSERJ publie des articles dans la langue dans laquelle ils sont soumis (français ou anglais).

\section{Diffusion initiale pour obtenir des commentaires}

Avant de soumettre un article à une revue, soit à des étrangers (i.e. évaluation à l'aveugle), il est recommandé d'obtenir des commentaires. Cela peut se faire lors de conférences ou en sollicitant des collègues ou un directeur de thèse. II n'est pas nécessaire que ces collègues soient spécialistes du sujet. Choisissez plutôt des personnes avec qui vous avez une relation de confiance, qui ont des perspectives variées et qui connaissent bien le processus de publication et votre de travail. Les meilleurs conseils proviendront de personnes n'ayant pas d'intérêt à protéger et qui pourront vous donnez l'heure juste.

\section{SOUMISSION ET ÉVALUATION}

Soumettre un article et ne pas faire de suivi est comme frapper un coup-sûr au baseball sans courir sur les buts. Vous devriez recevoir un accusé de réception peu après votre soumission. Sinon, il est important de s'informer si l'article a bien été reçu, en particulier lorsqu'il s'agit d'un système de soumission électronique, où il peut y avoir des problèmes techniques. Si vous ne recevez rien du rédacteur en chef après quelques semaines, vous pouvez supposer que votre article a été transmis à des évaluateurs externes. Le processus d'évaluation 


\section{Elson and / et Brouard (2012)}

est un processus qui peut durer un minimum de quatre à six semaines ou plus longtemps selon la période de l'année. II faut donc être patient.

\section{Décision initiale du rédacteur en chef}

Lorsqu'il reçoit un article, le rédacteur en chef examine l'article pour voir s'il correspond aux objectifs et aux règles de la revue. II est possible que le rédacteur en chef décide de demander des révisions avant de transmettre l'article aux évaluateurs. S'il y a des lacunes dans l'article, telle que l'absence d'une revue de la littérature ou d'une section sur la méthodologie, il est préférable de corriger ces éléments avant la transmission aux évaluateurs. L'absence de certaines composantes importantes reflète un manque de préparation avant la soumission. Le rédacteur en chef peut aussi suggérer de soumettre l'article à une autre revue, si le sujet n'est pas approprié.

\section{Évaluation à l'aveugle et décision}

L'évaluation à l'aveugle signifie que les évaluateurs ne connaissent pas les noms des auteurs et vice versa. Le processus est géré de manière à protéger l'anonymat des auteurs autant que des évaluateurs. Tous les évaluateurs sont choisis pour leur expertise et pour atteindre les principes de qualité. II est demandé aux évaluateurs d'ANSERJ de divulguer la possibilité de conflits d'intérêt en lisant le résumé ou subséquemment. En cas de conflits d'intérêt, on sélectionne un autre évaluateur. La plupart des évaluateurs sont très occupés, alors ANSERJ fait de son mieux pour choisir les évaluateurs avec une expertise pertinente à l'article. II en résulte une évaluation de qualité.

ANSERJ identifie au moins deux ou trois évaluateurs pour chaque article. Ces évaluateurs proviennent de partout au monde. Les évaluateurs d'ANSERJ écrivent fréquemment plusieurs pages de commentaires et de suggestions. Ceci est particulièrement utile aux auteurs pour améliorer la qualité de leur article et pour appuyer leur développement personnel. Même si cela peut être déstabilisant et parfois frustrant, il est particulièrement utile de lire en profondeur les commentaires des évaluateurs pour deux raisons. Premièrement, les évaluateurs ont différentes perspectives et il faut parfois travailler à les concilier. Deuxièmement, les rédacteurs en chef d'ANSERJ, comme ceux de nombreuses revues, s'attendent à la révision de l'article et à l'identification des changements dans un document distinct.

Peu importe la nature des commentaires reçus, il faut y voir de fortes suggestions. Au cas où les commentaires soient contradictoires, il y faudra un arbitrage de la part des auteurs, en collaboration avec le rédacteur en chef insistera sur certains points particuliers. II est important de rappeler que des révisions multiples et la soumission à nouveau est la norme et non l'exception pour une revue avec comité de lecture. Lorsque vous intégrez les révisions, il est important de comprendre qu'il s'agit de recommandations et non de directives strictes. Si vous justifiez clairement votre position sur les révisions non effectuées, il est possible de le faire. En général, faire des révisions ajoute à la longueur de l'article, mais il faut toujours faire attention à la clarté, à la cohérence et à la concision.

Suite à la réception des commentaires des évaluateurs, un rédacteur peut rejeter un article pour plusieurs raisons. II peut s'agir de problèmes au niveau de la question de recherche, d'un design de recherche déficient, d'une ambivalence dans le propos, d'un manque de cohérence ou d'une pauvreté de contribution au domaine de recherche (Mautz, 1987). Lorsque les remaniements sont trop nombreux, il est souvent préférable de rejeter l'article plutôt que de s'acharner pour l'améliorer. Si on espère obtenir un article de qualité, des remaniements légers ou profonds seront requis. Bien sûr, l'histoire nous apprend que le processus est complexe et que les rédacteurs eux-mêmes fassent des erreurs d'évaluation, comme dans le cas des articles classiques soumis par des gagnants de Prix Nobel (Gans et Shepherd, 1994), où plusieurs articles ont été rejetés par diverses revues. 


\section{Elson and / et Brouard (2012)}

Nous faisons de notre mieux pour offrir à chaque article une évaluation juste et équitable, en fournissant des conseils tout au long du processus.

Chez ANSERJ, le rédacteur en chef est responsable du contenu avant l'édition et du formatage par la maison de publication de la revue. Cela entraîne d'autres responsabilités au niveau du suivi des commentaires rédigés par les évaluateurs, du texte révisé par les auteurs et de l'édition selon les normes de la revue. À cette étape, l'auteur fournit des notes biographiques, si ce n'est pas déjà fait, et des remerciements, si cela convient.

\section{CÉLÉBREZ VOTRE SUCCÈS}

La publication de votre article constitue une réalisation personnelle et professionnelle. Vous pouvez appuyer la revue et donner un élan à votre carrière en diffusant la nouvelle de la publication de votre article. Songez à diffuser le titre et le résumé de votre article sur les réseaux sociaux et les sites web; mettez à jour votre curriculum vitae afin d'inclure cette nouvelle publication. De son côté, ANSERJ distribue tous ses articles via OJS (Open Journal Systems), ProQuest et EBSCO. On a également transmis une demande afin qu'ANSERJ soit disponible sur une base de données au Royaume-Uni.

À chaque entrée dans un processus de soumission et de publication, certains apprentissages ont lieu. Les auteurs ayant du succès sont ceux qui apprennent et s'améliorent au fil du temps. En s'attardant à chaque étape, il est possible d'obtenir plus de succès dans la soumission et dans la publication d'articles et ainsi d'éviter des frustrations inévitables.

\section{CONCLUSION}

Souvent, le mystère relié à la publication a ses racines dans une connaissance inadéquate par rapport au processus lui-même. Nous espérons que ces conseils, jumelés avec votre talent et votre persévérance, amèneront des améliorations dans vos textes et dans notre revue. Contribuer à la connaissance est le but principal de la recherche et la diffusion des connaissances est la raison d'être de notre revue.

\section{REFERENCES / BIBLIOGRAPHIE}

Adler, R., \& Liyanarachchi, G. (2011). An empirical examination of the editorial review processes of accounting journals. Accounting and Finance, 51(4), 837-867.

ANSERJ. (2010). Author Guildelines. URL: http://www.anserj.ca/index.php/cjnser/pages/view/submissions

De Lange, P.A. (2005). The Long Road to Publishing: A User-friendly Exposé. Accounting Education: An international journal, 14(2), 133-148.

Ellison, G. (2002a). The slowdown of the economics publishing process. Journal of Political Economy, 110(5), 947-993.

Ellison, G. (2002b). Evolving standards for academic publishing: A q-r theory. Journal of Political Economy, 110(5), 994-1034.

Gans, J.S., \& Shepherd, G.B. (1994). How Are the Mighty Fallen: Rejected Classic Articles by Leading Economists. Journal of Economic Perspectives, 8(1), 165-179.

Harrison, D. (2002). From the editors: Obligations and obfuscations in the review process. Academy of Management Journal, 46(6), 1079-1084.

Lemon, K. (2006). The Ultimate Guide to Scholarly Publishing. The Peer Review, (Spring/ Summer), S7- S11.

Mautz, R.K. (1987). The Refereeing Process. Accounting Horizons, 1(1), 91-92. 


\section{Elson and / et Brouard (2012)}

Maxwell1, J.A. (1998). Designing a Qualitative Study. In L. Bickman \& D.J. Rog (Eds.), Handbook of Applied Social Research Methods, (p. 69-100). Thousand Oaks: Sage Publications.

Swanson, E.P. (2004). Publishing in the Majors: A Comparison of Accounting, Finance, Management and Marketing. Contemporary Accounting Research, 21(1), 223-255.

Williams, J. M. (1995). Style: Toward clarity and grace. Chicago: University of Chicago Press.

\section{ABOUT THE AUTHORS / LES AUTEURS}

Peter R. Elson, PhD, is Senior Research Associate in the Institute of Nonprofit Studies, Mount Royal University, Calgary, Canada and English Language Editor for ANSERJ. Email: editor@anserj.ca

François Brouard, DBA, FCPA, FCA, est Professeur agrégé / is Associate Professor in the Sprott School of Business, Carleton University, Ottawa, Canada et rédacteur en chef de langue française pour ANSERJ.

Courriel: editor@anserj.ca 